DEPARTMENT OF THE INTERIOR

UNITED STATES GEOLOGICAL SURVEY

\title{
CHEMICAL QUALITY OF GROUND WATER FOR PUBLIC SUPPLY IN THE PHOENIX AREA, ARIZONA
}

By W. R. Osterkamp 